\title{
SUBGLACIAL MAZE ORIGIN IN LOW-DIP MARBLE STRIPE KARST: EXAMPLES FROM NORWAY
}

\author{
Rannveig Øvrevik Skoglund ${ }^{1}$ and Stein-Erik Lauritzen'1,2
}

\begin{abstract}
Maze caves or network caves are enigmatic in their evolution, as they form flow nets rather than more efficient, direct point-to-point flow routes. Network caves are often characterized by uniform passage dimensions in several directions, which indicates simultaneous dissolution of most available fractures. Nonshauggrotta in Gildeskål, northern Norway, is formed in low-dip marble strata and situated as a relict in a topographical and hydrological hanging position, thus lacking a modern drainage area. The cave displays a reticulate network geometry dictated by two orthogonal fracture sets. Passage morphology and paleocurrent marks in the cave walls (scallops) demonstrate that the cave evolved under water-filled conditions (phreatic) and that the relatively slow flow was directed uphill towards the confining aquiclude and the cliff face. In that sense, it has some resemblance to hypogene caves. However, we propose that the cave is a result of ice-contact speleogenesis, as it developed in the lee side of the Nonshaugen ridge under topographically directed glacier flow and seems independent of the otherwise variable flow regimes characteristic of the glacial environment.
\end{abstract}

\section{INTRODUCTION}

Karst caves in limestone are formed by dissolution when water aggressive with respect to calcium carbonate flows through integrated openings in the rock. This fundamental process results in a wide variety of cave geometries, controlled by the original porosity in the rock and hydraulic boundary conditions (Palmer, 1991). Maze caves are more enigmatic in their origin than meteoric or "common" caves (Ford and Williams, 2007), because maze caves consist of flow nets, in contrast to efficient point-topoint flow routes, as in linear and branchwork caves. Mazes evolve by simultaneous dissolution of all available fractures at similar rates, so conduits in these caves tend to be of equal dimensions. In accordance with this observation, two alternative mechanisms of maze origin are proposed (White, 1969; Palmer, 1975, 1991; Ford and Williams, 2007). Mazes can originate through diffuse, slow inter-formational recharge (transverse speleogenesis) (Klimchouk, 2009) or by recharge through repeated flooding in a variable fluvial regime. Diffuse recharge supplies all available fractures with solutionally aggressive water from an overlying or underlying unit, generally a sandstone, so that all fractures are dissolved and enlarged simultaneously and at similar rates. A similar effect occurs if there are short flow paths from where water enters the rock, causing all fractures except for the tightest to enlarge simultaneously at similar rates, as in epikarst (Palmer, 2002).

Flooding causes temporal variation in discharge and steepening of the hydraulic gradient, forcing aggressive water into available fractures, which accordingly dissolve at similar rates (Palmer, 2001). High discharge and high hydraulic gradient may occur in hydraulic regimes with great variability, as in the epiphreatic or flood-water zone of river caves. A particularly efficient situation occurs when a trunk passage is choked due to collapse. Here, the damming effect of the constriction increases the hydraulic head and amplifies the effect of floods, which will force water into all available fractures (Palmer, 2002).

Maze caves are loci of extreme karst porosity that, like large chambers, are possible precursors to breccia zones in paleokarst (see for instance mechanisms suggested by Loucks, 1999). Areas of moderate to high karst porosity are of major importance for the capacity and yield of groundwater aquifers, for mineralization, and for petroleum migration in carbonate reservoirs. This is part of the motivation for understanding the speleogenetic mechanisms for maze caves.

\section{Maze Caves in Stripe Karst}

Maze caves are quite common in the stripe karst of central Scandinavia. Stripe karst occurs in thin layers of marble interbedded with layers of impermeable bedrock, mainly mica schist (Horn, 1937; Lauritzen, 2001). Stripe karst often has great lateral extent and intersects the land surface at an angle. The insoluble aquicludes provide both geometric and hydrologic constraint to cave development. Accordingly, the caves in stripe karst are essentially twodimensional. Metamorphic alteration has removed all original porosity in the rock, so that all pre-karst water circulation, and thus speleogenetic inception, is restricted to fractures, faults, and lithological contacts developed

\footnotetext{
${ }^{1}$ Department of Earth Science, University of Bergen, Allégaten 41, N-5007 Bergen, Norway. rannveig.ovrevik@geo.uib.no

${ }^{2}$ Department of Plant and Environmental Sciences, The Norwegian University of Life Sciences, 1532 Ås, Norway. Stein.Lauritzen@geo.uib.no
} 
under post-metamorphic, brittle regimes. This gives predictable boundary conditions and makes caves in stripe karst favorable for analysis and modeling.

During the Quaternary, repeated glaciations of variable duration and extension (e.g., Sejrup et al., 2000) shaped the landscape of western Scandinavia, and thus, the stripe karst. The karst hydrological regime has varied according to the climatic conditions between the extremes of fluvial, during interglacials similar to the present, and subglacial, during glaciations with thick continental ice-sheets.

The orientations and dips of fractures and lithological contacts and the connectivity between fractures and interfaces are the most important passive factors for speleogenesis in a given rock mass. Their intersections with the surface define input and output boundaries for the karst. Water recharge and water chemistry are active factors. Lauritzen (2001, p. 75) examined how passive factors constrain cave patterns in stripe karst and found that "the various morphotypes show systematic dependence on stratal dip of the allogenic stripe contacts, of the type of contacts, and to a lesser extent, the fracture patterns," where type of contact means aquifer type (i.e., confined, unconfined, or perched). However, there is considerable overlap between the occurrence of maze caves and other cave patterns with respect to these parameters. In other words, a stripe karst setting does not give a complete explanation of maze evolution. Of the presently accepted mechanisms of maze origin, diffuse recharge seems quite improbable in the metamorphic stripe karst, with its impermeable wall rocks. Since many such mazes are situated in hanging positions in glacial valleys or at summits, isolated from any present-day fluvial drainage, the flood-water model is also not a satisfactory explanation of maze morphology in glacial stripe karst. Our hypothesis is that, in this geological setting, aspects of the subglacial or ice-contact regime may have been responsible for mazecave evolution.

Paleocurrents in and speleogenesis of a tiered maze cave in strata dipping steeply more than $60^{\circ}$ (Lauritzen, 2001), Pikhåggrottene in Rana, northern Norway, were previously described and analyzed by Lauritzen (1982). In the present work, we have examined a group of maze caves in stripe karst with lower dips of less than $30^{\circ}$ (Lauritzen, 2001), Nonshauggrotta and adjacent caves in Gildeskål, Nordland. The caves are relict and have a hanging topographic position, displaying a quite uniform passage geometry and morphology. This in turn suggests that the cave passages may have a correspondingly uniform history. Through detailed study of cave's geometry, passage morphology, flow function, and structural template, we aim at a closer understanding of both passive and, more important, the active factors of subglacial maze origin. These issues are further explored by survey and examination of Lønngangen, a small cave a few kilometers away, and two other small caves in Nonshaugen ridge.



Figure 1. The area north of Svartisen glacier with location of Nonshauggrotta and Lønngangen. White arrows show the direction of ice flow during maximum glaciation. Red arrows show the direction of glacier movement during the last deglaciation. Glacier flows from Rasmussen (1981).

\section{BACKGROUND}

\section{Geomorphological and Geological Setting}

Nonshauggrotta $\left(66^{\circ} 57^{\prime} \mathrm{N} 13^{\circ} 58^{\prime} \mathrm{E}\right)$ is located near the coast northwest of Svartisen glacier, northern Norway (Fig. 1). The area is characterized by glacially incised fjords and valleys, surrounded by mountains with alpine peaks reaching elevations of 800 to $1100 \mathrm{~m}$. Nonshauggrotta is situated on the northern side of Nonshaugen, a small, $300 \mathrm{~m}$ ridge at the end of Sørfjorden fjord. Nonshaugen has the shape of a glacial whaleback, with a steep lee side to the north and a more gently dipping stoss side to the south.

The cavernous carbonate essentially consists of calcite marble that was folded in several phases during the Caledonian orogeny (Gustavson, 1985; Stephens et al., 1985; Gustavson and Solli, 1989). The rocks of Nonshaugen contain a recumbent fold, the Nonshaugen fold, that is overturned to the north with a predominantly eastwest trend (Wells and Bradshaw, 1970). During the last phase, the rock sequence was folded to form an open antiform trending north-south, the Sørfjorden fold (Wells and Bradshaw, 1970), so that the Nonshaugen fold plunges to the east and west from the top of the hill (Fig. 2). The marble-schist interface in Nonshauggrotta dips gently southward $\left(082^{\circ} / 25^{\circ}\right)$. Although inclined stripe karst of this type may be considered covered karst, the exposure in the Nonshaugen wall is nevertheless a stripe karst. 




Figure 2. Low-dip stripe karst. Along the northern cliff face of Nonshaugen the low-dip marble-schist sequence crops out and makes the open Sørfjorden antiform visible.

\section{Glacial History}

In coastal areas, glaciation was not a continuous period of glacial cover, but rather a sequence of glacial advances of various durations and extents (e.g., Sejrup et al., 2000; Mangerud, 2004). According to Olsen (1997), the periods of ice growth and ice recession had durations of only a few thousand years during the period 15-40 ka BP. During maximum glaciation, ice flow in Gildeskål was westward (Rasmussen, 1981) (Fig. 1). The ice sheet was thick, so that flow was essentially independent of bed topography. During deglaciation, the ice thickness was reduced and ice flow was directed by the highest peaks and partly diverted into the main fjords and valleys. During the latest stages of glaciation, valley and fjord glaciers flowed from local ice masses at Svartisen and Glombreen (Rasmussen, 1981). Observations of glacial striations on the top and eastern side of Nonshaugen indicate an ice flow toward the northwest (302 to $316^{\circ}$ ), corresponding to a young, topographically directed ice flow. The rapid ice retreat after the maximum ice extent at about $18 \mathrm{ka}$ BP probably occurred partly through ice shelf break up and massive iceberg formation after a rapid global sea-level rise starting at about $15 \mathrm{ka}$ BP (Linge et al., 2007). Sørfjorden, and thus Nonshauggrotta, have been ice-free since Early Allerød time (13.7 ka BP) (Rasmussen, 1981).

\section{Methods}

Nonshauggrotta was first surveyed by Corbel (1957) and later by Holbye and Trones (unpublished plan map), and Lønngangen was surveyed by Eikeland (1986). However, our study required more complete and accurate three-dimensional cave maps with detailed geological information. Both caves were therefore resurveyed to BCRA grade 5C (Day, 2002), using passage-centerline polygons, where walls, ceiling, and floor are defined by their distance from each survey station. From survey data, 3-D models of the caves were obtained by using the Grottolf cave survey program (Lauritzen, 2004). During the survey process, the passage morphology was thoroughly examined, sketched, and photographed. The distribution and approximate grain size of surface sediments along the passage floor were also recorded. Guiding fractures (i.e., those fractures that had been widened into cave conduits by dissolutional enlargement) were logged, in addition to the marble-schist interface, foliations, and surface frac- tures. Some of the surface fracture were observed in the overlying mica-schist and in a stratigraphically higher marble layer.

Passage morphology reflects the hydrological conditions when they formed (e.g., Lauritzen and Lundberg, 2000). Under phreatic (water-filled) conditions, conduits form by corrosion in all directions outward from the passage center. This results in circular, elliptical, or lenticular passage cross-sections. Geological structures act as passive constraints on the passage shape. Under openchannel (vadose) conditions, corrosion and erosion only attack the floor, forming an incised canyon. A transition from phreatic to vadose conditions normally results in the keyhole shaped, two-stage cross-section.

Scallops are corrosional flow marks in the cave walls (Curl, 1974). They are imprints of the last active stage that lasted long enough for water to erase any previous scallop patterns. Scallop analyses were performed in accordance with the protocol described in Lauritzen (1982) and in Lauritzen and Lundberg (2000). From scallop symmetry and wavelength, paleocurrent direction was defined. Fluid velocity and, in turn, discharge can then be calculated from an estimate of water temperature $\left(+1^{\circ} \mathrm{C}\right)$ and passage dimensions. For statistical confidence, populations of at least 30 well-shaped scallops from the same area must be measured for discharge determination. However, flow direction can be deduced from a single well-developed scallop or a small group.

Variation in marble carbonate content was examined by loss-on-ignition (LOI) and acid-insoluble-residue tests of rock samples throughout the marble layer, and LOI was measured on two samples of mica schist from the confining beds. During the LOI tests at $800{ }^{\circ} \mathrm{C}, \mathrm{CO}_{2}$ is expelled from calcite $\left(\mathrm{CaCO}_{3}\right)$ and dolomite $\left(\mathrm{CaMg}\left(\mathrm{CO}_{3}\right)_{2}\right)$ in the rock, forming the corresponding oxides. Theoretical weight loss in pure calcite is $44 \%$ and in pure dolomite $48 \%$. Carbonates dissolve completely in $1 \mathrm{M}$ hydrochloric acid, and the residual is a measure of insoluble impurities present in the marble.

\section{Speleometric Characterization}

The cave survey program Grottolf provides several geometrical parameters of the void that can be used for its characterization. Cave length is the total length including all surveyed passage segments. Cave depth is the vertical difference between the highest and lowest elevated passage. 


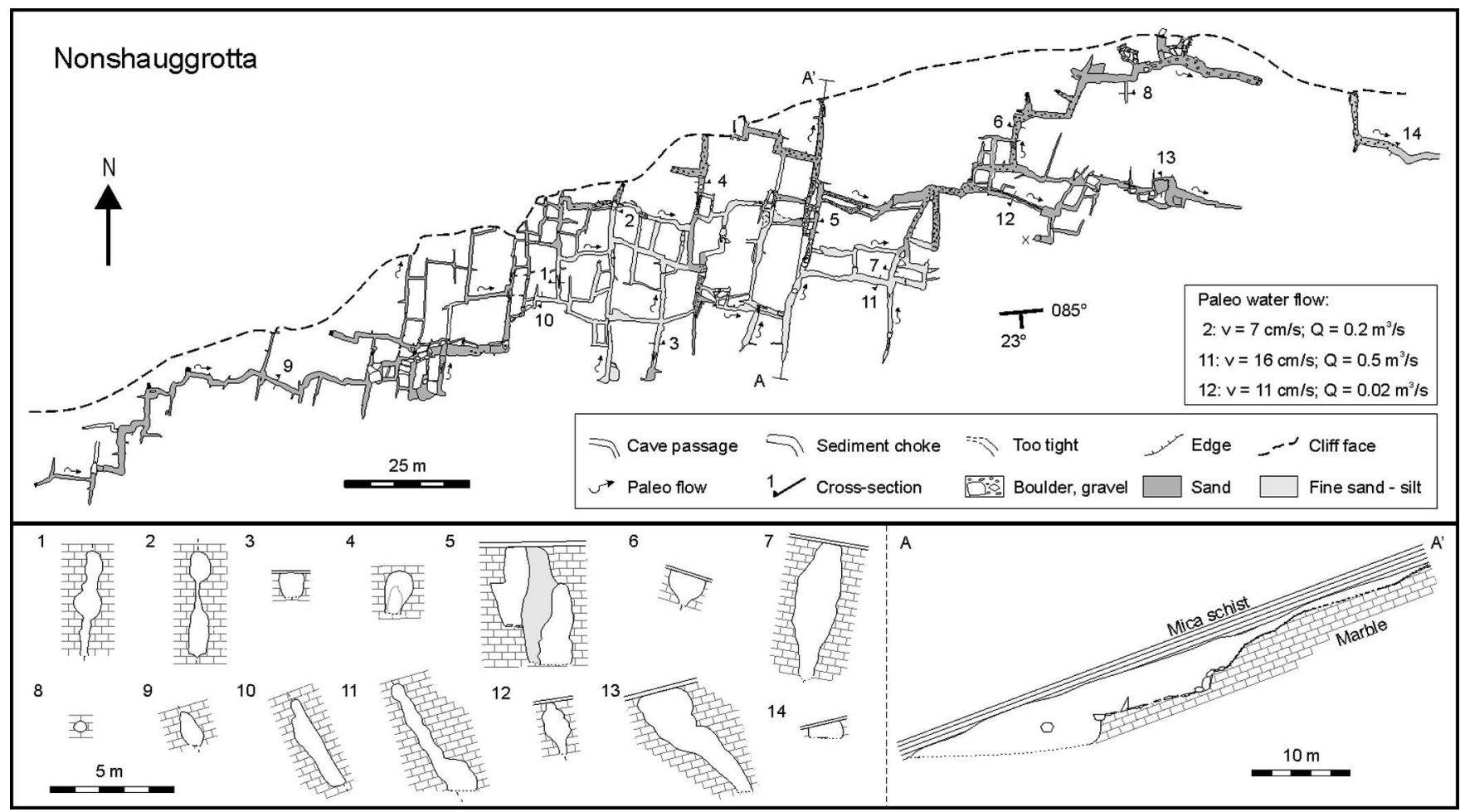

Figure 3. Plan map of Nonshauggrotta with passage cross-sections (5× exaggeration). A-A': Longitudinal (vertical) profile of a N-S passage $(2 \times$ exaggeration). $\times$ : Circular shaft. Site of scallops analysis refers to cross-section number. v: calculated paleocurrent velocity. Q: calculated paleo discharge.

Cave area is the total horizontal plan area of the passage outline. Cave volume is the total volume of all cave passages based on elliptical cross-sections. The rock area that encloses the cave is estimated as its convex hull, a polygon of only convex angles enclosing all cave passages in plan view. The rock volume that holds all cave conduits is here calculated as the convex hull area multiplied by the maximum passage height. From these data the following speleometric parameters can be calculated. Mean passage cross-sectional area (cave volume divided by cave length). Passage density (cave length divided by convex hull area). Areal coverage (cave area divided by the convex hull area expressed as percent). Cave porosity (cave volume divided by rock volume expressed as percent).

As a measure of how completely the cave fills a plane of projection, we use the fractal dimension or box dimension, determined by standard box-counting (Feder, 1988). The box dimension, $D$, of the cave can be calculated as (Simanca and Sutherland, 2002)

$$
D=-\lim _{\varepsilon \rightarrow \infty} \frac{\log N_{\varepsilon}(S)}{\log \varepsilon},
$$

where $N_{\varepsilon}(S)$ is the minimum number of two-dimensional squares of side-length $\varepsilon$ needed to cover the filled outline of the cave $(S)$. Accordingly, $D$ is the slope of the log-log plot of $N_{\varepsilon}(S)$ versus $\varepsilon$. This approach differs from the volumetric, modular method of Curl (1986), but serves our purpose best, because the cave is essentially twodimensional due to the stripe geometry, and it permits comparison with other caves where volumetric passage details are not available.

\section{RESUlts}

\section{Cave Description of Nonshauggrotta}

Nonshauggrotta was surveyed to a total passage length of $1.5 \mathrm{~km}$, at elevations between 231 and $260 \mathrm{~m}$ (Fig. 3). The highest passages are located in the northeast and along the cliff face. The passage density is quite high, $148 \mathrm{~km} /$ $\mathrm{km}^{2}$, as is the plane-filling fractal dimension, $D=1.5$ (Table 1). Explorable cave conduits penetrate less than $50 \mathrm{~m}$ down-dip from the cliff face, but extend nearly $300 \mathrm{~m}$ along it. The surveyed passages compose only a minimum estimate of the actual cave extent. Almost all southtrending conduits terminate in sand chokes; those that are open continue beyond explorable dimensions. Essentially all north-trending conduits end as openings in the cliff face, and were apparently truncated either by glacier plucking or by gravitational retreat of the cliff face. Therefore, the absolute boundary of cave passages cannot be established unambiguously, although our observations suggest that many passages taper out to small dimensions down-dip to 
Table 1. Speleometric data.

\begin{tabular}{lccc}
\hline Parameter & Nonshauggrotta & Lønngangen & Upper Nonshauggrotta \\
\hline Length, $10^{3} \mathrm{~m}$ & 1.5 & 0.30 & 0.23 \\
Depth, $\mathrm{m}$ & 29 & 12 & 36 \\
Cave area, $10^{3} \mathrm{~m}^{2}$ & 1.6 & 0.4 & 0.3 \\
Cave volume, $10^{3} \mathrm{~m}^{3}$ & 2.3 & 0.8 & 0.4 \\
Convex hull, $10^{3} \mathrm{~m}^{2}$ & 10.2 & 4.2 & 0.9 \\
Rock volume, $10^{3} \mathrm{~m}^{3}$ & 92 & 25 & 6 \\
Mean passage cross-sectional area, $\mathrm{m}^{2}$ & 1.5 & 2.8 & 1.9 \\
Passage density, $\mathrm{km} / \mathrm{km}^{2}$ & 148 & 70 & 256 \\
Areal coverage, \% & 16 & 9 & 36 \\
Cave porosity, \% & 2.5 & 3.2 & 7.0 \\
Fractal dimension & 1.5 & 1.2 & 1.1 \\
\hline
\end{tabular}

the south when followed deeper into the rock mass. So the density of cave voids appears to decrease in the down-dip direction.

\section{Structural Speleology}

The cave system displays a reticulated network architecture (Fig. 3). Cave conduits are oriented parallel with the strike and dip of the marble-schist interface $\left(082^{\circ} / 25^{\circ}\right)$, thus intersecting at nearly right angles. The predominate set of guiding fractures is steeply dipping, striking southsouthwest $\left(190^{\circ} / 79\right)$ (Fig. 4). The other set of guiding fractures has a moderate dip and strikes west-northwest $\left(282^{\circ} / 49^{\circ}\right)$. Only the predominate fracture set could be detected on the land surface above the cave (Fig. 4). We have not been able to detect any displacement along fractures or found other brittle kinematic indicators. At several locations, the west-northwest fractures terminate at the south-southwest fractures, though this relationship was not established unambiguously. However, if so, it implies that the south-southwest-trending fractures are older than the west-northwest-trending fractures. If not, the two fracture sets might have been formed simultaneously.

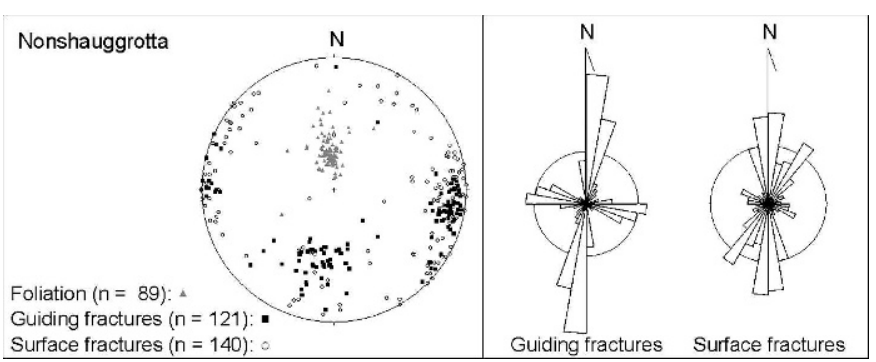

Figure 4. Left: Stereographic projection (equal area, lower hemisphere, magnetic north) of poles to foliation and fractures at Nonshaugen. Right: Rose diagrams (equal area, magnetic north) of trend of surface fractures and guiding fractures. Circle: $10 \%$.

\section{Morphology}

The passage cross-sections are high and narrow, with elliptical or irregular rift shapes reflecting the guiding fractures (Fig. 3). The passage cross-sections are related to the slope of the guiding fractures; south trending passages have vertical cross-sections, whereas west-trending passages have slanting cross-sections (Fig. 5). Mean passage cross-sectional area, approximated as ellipses, is estimated as about $1.5 \mathrm{~m}^{2}$. The largest measured cross-sectional area is about $16 \mathrm{~m}^{2}$ and is a result of breakdown modification. Dead end, tight fissures are common, while narrow vadose channel incisions are rare and, even when apparent, ambiguous. Where passages terminate in the cliff face and their entire cross-section is visible, they lack vadose incisions. In sum, the cave appears essentially phreatic, with negligible, if any, vadose modification. One of the southern conduits ends in a circular shaft $2 \mathrm{~m}$ deep plugged with sand and micaceous silt (Fig. 3).

\section{Mica-Schist Cap Rock}

The mica-schist ceiling forms a hydrological constraint that renders the cave system essentially two-dimensional. Passages were developed along and just below the upper marble-schist contact (i.e., in hydraulically confined settings) (Fig. 3).

Corrosional drip-pits in the marble underlying the schist ceiling demonstrate that seepage from the schist is occasionally acidic. Substantial efflorescence of gypsum on cave walls and rusty weathering of the mica schist reveal that iron oxides and sulfides are present in the mica schist, the sulfides having produced sulphuric acid by oxidation.

\section{Lithology}

The results from the loss-on-ignition and acid-insoluble-residue tests are inversely proportional $(\mathrm{r}=-0.99)$, and consistent. The insoluble residuals were in the range 1 to $21 \%$ (Fig. 6), which indicate that the purity of the marble is variable, with between 79 and $99 \% \mathrm{CaCO}_{3}$ and $\mathrm{CaMg}\left(\mathrm{CO}_{3}\right)_{2}$. However, the composition of the upper, 

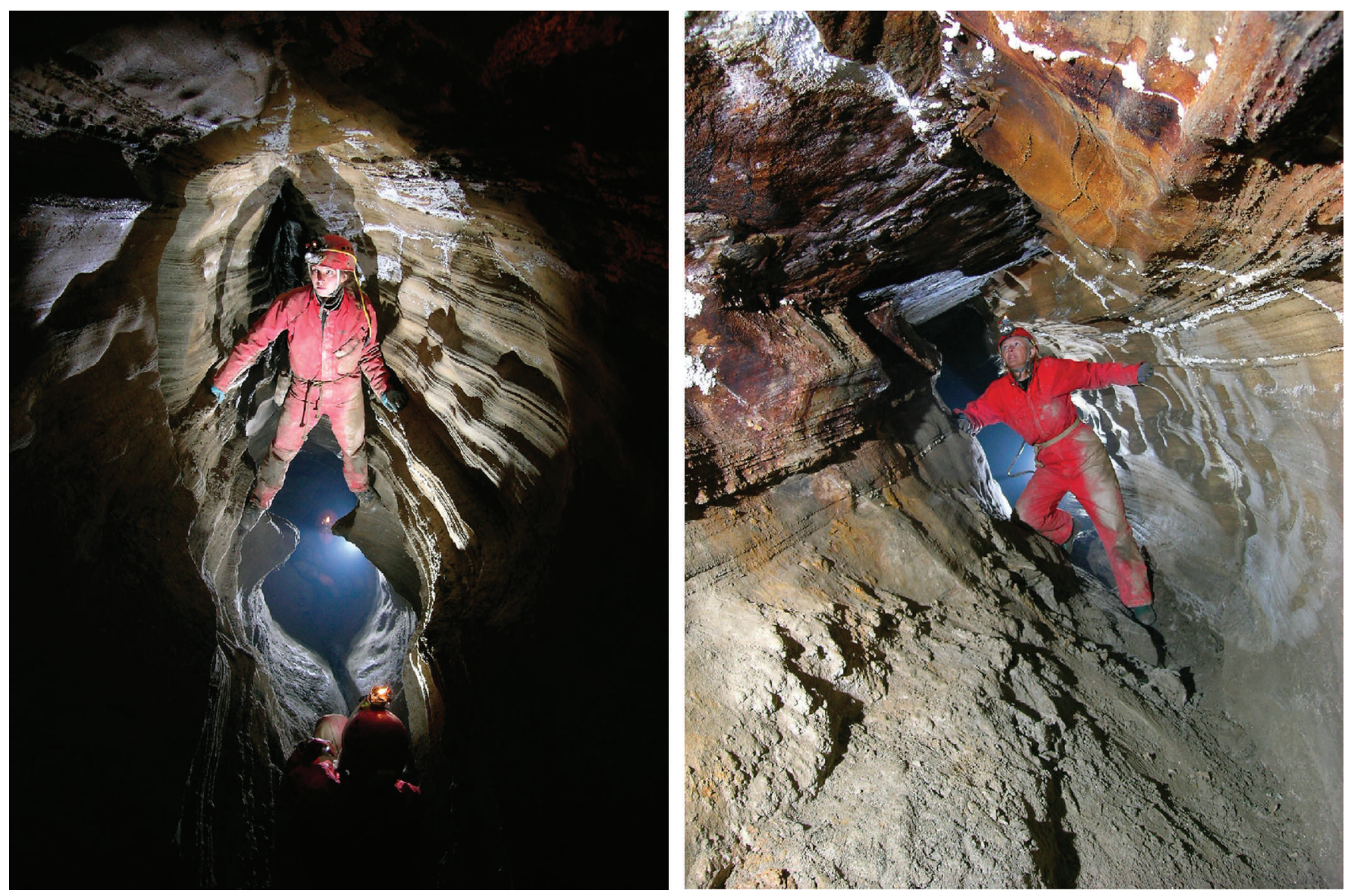

Figure 5. Passages of Nonshauggrotta with distinct guiding fractures. Left: south-trending passage with subvertical guiding fracture. Right: west-trending passage with moderately dipping guiding fracture, mica schist ceiling, efflorescences of gypsum and hydromagnesite, rusty coloring, and fine sediments on lower wall and floor.

cavernous part of the marble layer, where cave conduits occur, does not differ from the rest of the marble layer either in loss-on-ignition ( $t$-test, $t_{17}=-0.67, p=0.51$ ) or acid insoluble residual ( $t$-test, $t_{17}=0.55, p=0.59$ ). Consequently, variation in marble purity fails to explain the stratigraphic position of the cave conduits adjacent to the confining strata in the sequence. The absolute content of insoluble residue is quite high, but has not choked off speleogenesis, probably because mica and quartz do not swell in contact with water.

\section{Sediments}

The passage floor consists essentially of fine to coarse sand (Fig. 3). Mica is abundant and seems to dominate the coarser sand fractions. Some of the northern passages contain pebbles and cobbles. Angular breakdown occurs in a few of the largest passages. Some of the north-trending passages are plugged by breakdown and scree material that penetrated from the cliff face. No varved, clayey sediments have yet been found in the cave, and the layers of sand and gravel are probably a fluvial lag.

\section{Paleohydrology}

Nonshauggrotta is relict and dry and lacks a modern drainage area due to its topographic position in the northern cliff face of Nonshaugen, in the lee side of the glacial whaleback. Scallops in conduit walls and ceiling display a consistent flow pattern, eastward in east-west trending passages and northward in north-south trending passages (Fig. 3). Accordingly, water flow was upward, artesian, and the hydraulic gradient was directed toward the northeast. Hence the network had an effluent flow under phreatic conditions; it represented the discharge boundary of the karst aquifer. The Sauter mean of scallop length, $L_{32}$, was deduced from scallop populations in three different sites (Fig. 3), $32 \mathrm{~cm}$ at one site and $20 \mathrm{~cm}$ at two other sites. Calculated paleoflow velocities were in the range of 7 to $16 \mathrm{~cm} \mathrm{~s}^{-1}$, while paleodischarges were in the range of 0.02 to $0.5 \mathrm{~m}^{3} \mathrm{~s}^{-1}$. Although only a few sites were suitable for statistical analysis of scallops, numerous other observations indicate that scallop lengths throughout the network are within the same size range. We were unable to detect any variation in mean scallop length with height above the passage floor. 




Figure 6. Loss-on-ignition and acid-insoluble-residue from 19 marble samples and 2 mica-schist samples (only LOI) from the marble layer in which Nonshauggrotta is situated (cave position marked in black).

\section{Other Caves and Karst Features in Nonshaugen}

Upper Nonshauggrotta is situated about $100 \mathrm{~m}$ south of Nonshauggrotta in a stratigraphically higher marble layer at an elevation of about $285 \mathrm{~m}$, but in a similar position below an upper marble-schist interface (Fig. 7). The cave was surveyed to a length of $175 \mathrm{~m}$ and a depth of $36 \mathrm{~m}$. The lower part of the cave is a shaft slanting downward at about $36^{\circ}$ and trending south, ending in a breakdown choke at the bottom of a $3 \mathrm{~m}$ vertical drop (Fig. 7). In its upper part, the cave consists of two stories and some branches and loops. Morphology and scallops indicate that paleoflow was slow and uphill.

A small cave is situated at the southern side of Nonshaugen, at an elevation of approximately $140 \mathrm{~m}$, here termed Small Cave (Fig. 7). The cave is a single passage trending north and plugged by sediments after about $30 \mathrm{~m}$. This passage is mainly in schist with an angular and irregular cross-section, indicating that it has migrated upward by breakdown from the dissolutional conduit in the underlying marble unit.

Four dolines were noted in the upper marble layer at the top of the western side of Nonshaugen ridge (Fig. 7). Three small dolines ( 2 to $5 \mathrm{~m}^{2}$ in cross-sectional area and 0.6 to $1.2 \mathrm{~m}$ deep) are situated in a row oriented east-west. South of these dolines lies a single larger doline, about $8 \mathrm{~m}$ in diameter and $3.7 \mathrm{~m}$ deep.



Figure 7. Upper: Aerial photograph of Nonshaugen with caves. A-A': Line of cross-section. Lower: Vertical crosssection of Nonshaugen. Marble-schist contacts in the middle of the ridge are hypothesized. Red arrows: paleoflow direction from scallops. Grey arrows: Topographically directed ice flow (in accordance with Rasmussen 1981).

\section{LøNNGANGEN}

Lønngangen $\left(67^{\circ} 00^{\prime} \mathrm{N} 13^{\circ} 57^{\prime} \mathrm{E}\right)$ is situated on the peninsula west of Sørfjorden (Fig. 1). The cave is located on the western limb of the Sørfjorden fold. Accordingly, the marble-schist interface dips gently toward the westsouthwest $\left(154^{\circ} / 11^{\circ}\right)$.

Lønngangen was surveyed to a length of about $300 \mathrm{~m}$. The cave has four openings in a cliff face less than $10 \mathrm{~m}$ high, at elevations between 60 and $70 \mathrm{~m}$. In plan view, the cave has an angular pattern (Fig. 8). Compared to Nonshauggrotta, the cave has a low passage density of $70 \mathrm{~km} / \mathrm{km}^{2}$ and a low fractal dimension of 1.2 (Table 1). The passage morphology and geometry are dictated by two orthogonal sets of steeply dipping guiding fractures. The guiding fractures strike southwest $\left(216^{\circ} / 75^{\circ}\right)$ and northwest $\left(315^{\circ} / 74^{\circ}\right)$ (Fig. 9). Passages are essentially high and narrow rifts with a mean cross-sectional area of $2.8 \mathrm{~m}^{2}$ in 




Figure 8. Plan map of Lonngangen with passage cross-sections (3× exaggeration).

elliptical approximation (Fig. 8). A few small, sub-circular side conduits intersect the main passage and form closed loops. Negligible vadose modification is seen, and marble breakdown occurs in only a few places, most prominently by the eastern entrance. Sandy sediments compose the passage floor, and shell sand plugs the innermost conduit. Sub-rounded gravel occurs in a few places (Fig. 8). The mica-schist cap rock frequently forms the ceiling of the passages (Fig. 8). Corrosional drip-pits are found on marble boulders below mica-schist exposures.

The paleoflow direction deduced from scallops is from east to northwest (Fig. 8). The eastern entrances conveyed water into the rock, while water emerged from the northwestern entrances (Fig. 10). Accordingly, the cave contains a complete flow route between input and output boundaries at the topographic surface.

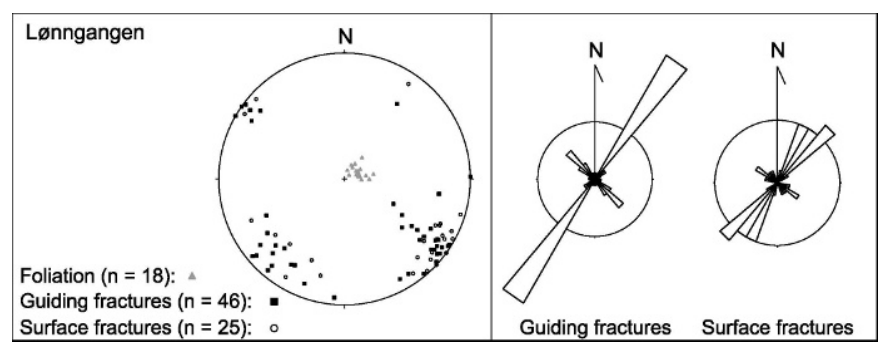

Figure 9. Left: Stereographic projection (equal area, lower hemisphere, magnetic north) of poles to foliation and fractures from Lønngangen. Right: Rose diagrams (equal area, magnetic north) of trend of surface fractures and guiding fractures. Circle: $\mathbf{2 0 \%}$.

\section{DisCUSSION}

\section{Structural Guiding}

Nonshauggrotta and Lønngangen are each guided by orthogonal fracture sets. However, the fracture sets of the two caves have different orientations.

In the map of tectonic lineaments of Norway (Gabrielsen et al., 2002), the regional trends of Nordland and Troms are northeast-southwest and northwest-southeast. On the map, lineaments trending north-northeast-southsouthwest and west-northwest-east-southeast are abundant in the Gildeskål area, whereas lineaments trending north-south, east-west, and northeast-southwest are present but sparse. North to north-northeast is also the regional Caledonian strike direction and the axial trend of the Sørfjorden antiform.

The two sets of guiding fractures of Nonshauggrotta are parallel to the pronounced trends of tectonic lineaments in the Gildeskål area. In Nonshaugen, the south- to southsouthwest-striking fracture set is dominant. This fracture set guides the passage trends in the Nonshaugen caves and is the single pronounced fracture set on the surface above the cave. The west-northwest-striking fractures were only detected within Nonshauggrotta. We assume that by logging surface fractures in the vicinity of the cave, the true fracture distribution is identified. However, here the attitude of the west-northwest-striking fracture set may have made it less pronounced in surface outcrops.

The southwest- and northwest-striking guiding fractures in Lønngangen are consistent with surface fractures (Fig. 9), local lineaments determined from aerial photos (Fig. 10), and the regional lineament trends in Nordland and Troms (Gabrielsen et al., 2002). On the other hand, they differ from the south-southwest and west-northwest 




Figure 10. Upper: Aerial photograph of the area around Lonngangen. A-B: Line of cross-section. Lower: Vertical cross-section of Lonngangen with topography. Black: cave passages. Red arrows: paleowater flow direction from scallops. Grey arrows: Topographically directed ice flow (in accordance with Rasmussen, 1981).

strike of guiding fractures found in Nonshauggrotta. This pronounced difference in fracture sets may be related to the location of Lønngangen at the limb of the fold of the Sørfjorden antiform, whereas Nonshaugen is situated in the hinge of the fold.

The fractures predate the speleogenesis in the metacarbonates. Otherwise, there is no unequivocal evidence of chronological relationships between the fracture sets. Since the Devonian, the regional tectonic stress field has varied significantly (Bergh et al., 2007), and it does not seem prudent, on the basis of this locality, to associate the local fractures with specific phases of the regional geological history.

\section{Stratigraphic Cave Position}

The lack of correlation between marble purity and concentration of cave voids in Nonshauggrotta suggests that the stratigraphic position of the cave is controlled by hydrological factors rather than the distribution of solubility. It is conceivable that the position of the cave is a result of artesian flow towards a low-dip confining contact.

Occurrence of iron oxides and pyrite in the mica schist suggests that cave inception may have been aided by sulfuric-acid speleogenesis at the marble-schist interface.

\section{Paleohydraulic Function}

\section{Flow Direction and Flow Components}

All interpretations of paleocurrents are based on scallop morphometry and surface sediments at the passage floor, all of which are remnants of the last active stage. Our interpretations, therefore, primarily concern the last stages of evolution.

In Nonshauggrotta, the passage cross-sections indicate symmetrical dissolution outward from the guiding fractures under phreatic conditions. Artesian water flow, deduced from scallops, is consistent with evolution under confined settings. In accordance with the paleocurrent direction, the southern vertical conduit (Fig. 3) is interpreted as a phreatic artesian feeder. Since several passages seem to taper out southwards into the rock mass, we suggest that only a few riser tubes fed the system from below. Upper Nonshauggrotta displays the same flow function and conduit pattern as Nonshauggrotta, feeder tubes and distributary networks, although more fragmentary due to its smaller size (Fig. 8). This supports the interpretation of artesian water flow from the south through an effluent flow network. The low-dip, confining aquiclude may have caused a spreading and slight retardation of the flow, and thus, enhanced maze formation. The rudimentary network evolution in Upper Nonshauggrotta may be partly attributed to the steeper dip of the marble-schist interface except in the upper, outermost part.

The stratigraphic position of Small Cave at the southern side of Nonshaugen may align with either Nonshauggrotta or Upper Nonshauggrotta. It might therefore be an example of an influx conduit feeding the cave network from the southern, stoss side of the glacial whaleback.

The deduced hydraulic gradient direction toward the northeast and the consistent flow direction towards the east in the western part of the cave and in east-west passages together imply that there might have been additional recharge from the western or southwestern side of the ridge, giving a flow component sub-parallel with the cliff face. This may be considered as a sort of flank margin subglacial pattern of genesis or perhaps flank margin adaptation of a covered or confined network of conduits. However, there is no sign of solution sculpture by flow into or out of the cave in the northern cliff-face.

\section{Slow Paleocurrent}

As scallop lengths seem to be quite consistent throughout Nonshauggrotta, the mean paleoflow velocity in the cave system as a whole is similar to the spot observations of calculated velocities (a few tens of $\mathrm{cm} \mathrm{s}^{-1}$ ). Slow flow conditions were also observed in Upper Nonshauggrotta. Low flow velocities are also consistent with the widespread deposits of fine-grained sediments. According to the Hjulstrøm diagram (Sundborg, 1956), fine sand is deposited at velocities of less than $20 \mathrm{~cm} \mathrm{~s}^{-1}$, while coarse sand is 
deposited at velocities less than $40 \mathrm{~cm} \mathrm{sec}^{-1}$. Discharge determined from scallops has been shown to represent discharges within the highest 2 to $15 \%$ of the annual flows (Lauritzen, 1989; Lauritzen and Lundberg, 2000). The conspicuous lack of coarse fluvial lag material further supports the impression that low velocities have dominated the network flow.

\section{Speleogenetic Setting}

Based on the cave geometry, passage morphology, hydraulic function, and topographically and hydrologically hanging position, several different origins of Nonshauggrotta may be considered: (1) hypogene origin, where the aquifer is fed from below and without relation to surface drainage, (2) post-glacial or late interglacial origin, in a topographical position similar to the present, (3) pre-glacial or early interglacial origin, as a flood-water maze in the bottom of a fluvial valley; and (4) subglacial origin, in a topographical position similar to the present and in contact with a glacial aquifer as part of a subglacial drainage network.

The network geometry and the effluent flow function are suggestive of caves of hypogene origin (Klimchouk, 2003, 2009). However, this sort of hypogene speleogenesis is characterized by water injection from a porous aquifer below or above the soluble strata, and the presence of impermeable strata in stripe karst makes a hypogene origin implausible. In contrast to isolated maze caves, which are typically formed in confined aquifers by a locally generated boost of the groundwater aggressivity (Frumkin and Fischhendler, 2005), the network of Nonshauggrotta is an integrated cave system that was formed by water that was already aggressive when injected into the marble.

Pyrite or sulfide oxidation could have been a source of locally generated aggressiveness when ascending groundwater mixed with oxygenated surface water. For pyrite, the total reaction is

$$
\begin{aligned}
& 4 \mathrm{FeS}_{2}+16 \mathrm{CaCO}_{3}+15 \mathrm{O}_{2}+14 \mathrm{H}_{2} \mathrm{O}= \\
& 16 \mathrm{Ca}^{2+}+16 \mathrm{HCO}_{3}^{-}+8 \mathrm{SO}_{4}^{2-}+4 \mathrm{Fe}(\mathrm{OH})_{3} .
\end{aligned}
$$

One formula weight unit of pyrite can dissolve four formula weights of calcite, or by volume $1 \mathrm{~mm}^{3}$ pyrite would dissolve $6.4 \mathrm{~mm}^{3}$ marble and leave a considerable amount of insoluble hydrated iron oxide. The iron hydroxide will act as a surface inhibitor. If speleogenesis was based on pyrite oxidation alone, the dissolution of the marble would have required $16 \%$ of its volume in pyrite. Therefore, it is evident that the modest sulfide concentration (no pyrite grains have been directly observed) in the upper mica-schist layer is not enough to account for the total volume of the cave, so that the sulfuric-acid mechanism could only have been important at the caveinception stage. It is, however, quite conceivable that oxygenated water, either directly from the surface or from the glacier environment, combined with some sulfide, might have been crucial in establishing integrated flow at the very commencement of speleogenesis.

Phreatic formation of the caves in Nonshaugen requires that the water table was above the top of the caves. Two different settings have provided high water tables in the past: bedrock, before the valley was entrenched, and glaciers, when they filled the valley and raised the water table in the adjacent rocks. The caves of Nonshaugen and Lønngangen lacked a surface drainage area during past and present interglacials due to their hanging position in the cliff face. Consequently, post-glacial or late interglacial origin of the caves is rejected.

In previous works, valley erosion rates by glaciers have been estimated to range from 15 to $55 \mathrm{~m}$ per $100 \mathrm{ka}$ (Lauritzen, 1990, and references therein; Nesje and Sulebak, 1994). This implies a minimum of $500 \mathrm{ka}$ since Nonshauggrotta may have been situated below the valley floor. Small passage cross-sectional areas indicate a short evolution time because "after a passage reaches the maximum annual enlargement rate, its size depends mainly of the length of time it contains flowing water" (Palmer, 1991, p.10). Under subglacial settings the cave conduits tend to be water-filled, and active water circulation, and thus dissolutional widening, occurs at least occasionally (Ford, 1977; Lauritzen, 2006). Small passage dimensions are inconsistent with evolution in a valley bottom during fluvial regimes and repeated subglacial conditions, and preglacial or early interglacial evolution of Nonshauggrotta as a floodwater maze in the valley bottom is rather improbable.

The most probable setting for artesian conditions in this topographic and geological environment is subglacial. Subglacial and englacial water drainage is controlled by the surface slope of the glacier and is essentially independent of bed topography. Water flow toward the northeast in Nonshauggrotta and toward the north in Upper Nonshauggrotta is consistent with observed glacial striations toward the northwest on the eastern side of the ridge and with younger, topographically directed glacier flow (Rasmussen, 1981) (Fig. 7). When directed by the topography, the glacier would flow over the summit and around Nonshaugen, so that both the southern and western side of the ridge have been subject to high pressure. Effluent flow is consistent with the network occurring at the lee side of the ridge. The consistently slow flow rates observed in the Nonshaugen caves may be due either to great glacier thickness with a gentle surface slope or something else that damped the strong fluctuations of glacial flow.

The observed flow direction in the caves is perpendicular to the direction of glacier movement during full glaciation. A gentle glacier surface slope parallel with the observed direction of water flow is therefore more likely to correspond to early periods of deglaciation, when the mountains in the west started to control the glacier flow and turned it northward. During deglaciation it can be assumed that high flow rates occurred during the melting 
season. The lack of signs or remnants of high flow rates or flushing, such as coarse-grained lag, suggest that the cave was not exposed to the natural fluctuations of meltwater discharge. Accordingly, we suggest that some control of the flow occurred in the karst system or in the contact between the karst system and the glacier. A glacier is a dynamic aquifer with an ephemeral drainage pattern and discharge, and the maze was established in the lee side of the hill. Accordingly, we suggest that restricted outflow towards the ice contact has caused network evolution in the outflow zone. Modeling experiments by Skoglund et al. (2010) support this interpretation.

\section{SPELEOGENESis of LøNNGANGeN}

The underlying cave pattern of Lønngangen cannot be decided unequivocally due to its small size and fragmentary form. We suggest that it is a rudimentary or degenerated network cave; it either never developed into a proper network or has been truncated and partly destroyed by glaciers. Water flow in Lønngangen was parallel to the cliff face and the cap-rock contact, not toward them (Fig. 10). This contrasts with the setting of Nonshaugen, and the lack of outflow restriction is a possible explanation of the rudimentary network pattern.

The passage morphology in Lønngangen also indicates symmetrical dissolution around steeply dipping guiding fractures under phreatic conditions. Lønngangen was situated below sea level for about $4 \mathrm{ka}$ after the last deglaciation (ML $89 \mathrm{~m}$ a.s.l., Rasmussen, 1981), since sea level did not drop below the cave level until the Boreal. However, the phreatic passage morphology, the small passage cross-sections, and the cave's location in the seafacing cliff indicate that the cave is quite young and, in accordance with the previous discussion of Nonshauggrotta, has probably developed under subglacial conditions. The paleocurrent direction deduced from scallops in Lønngangen is not compatible with submarine or shoreline erosion. Paleocurrent direction is consistent with glacier flow during both full glaciation and deglaciation (Figs. 1 and 10). However, it is conceivable that there was less water available below the glacier during full glaciation, and accordingly, that water circulation and dissolution were more efficient during glacial retreat and advance.

\section{Conditions of Subglacial Speleogenesis}

The homogeneous character and lack of modifications of the passage morphology in Nonshauggrotta suggest that evolution either has been continuous or the cave evolved through a series of stages with a quite similar hydrological regime. Glaciations are characterized by strong fluctuations in hydrology, both on a short time scale (annually) and on a long time scale (glacial/interglacial cycles). Accordingly, active subglacial solutional widening of karst aquifers is most likely disrupted by periods of stagnation, possible silting up, and drained periods during interstadials and interglacials (Ford, 1977).
We may estimate the age of Nonshauggrotta by considering the time required to form the passages under different wall-retreat rates. In an allogenic stream in a cave south of Svartisen glacier, the dissolution rate is estimated at $0.2 \mathrm{~mm} / \mathrm{a}$ in an unpublished study by Lauritzen, so a scallop relief of about $2 \mathrm{~cm}$ would require about 100 years under interglacial conditions to be established or replace a previous pattern. From corrosion of an interglacial speleothem, Lauritzen (1990) reported a total subglacial solutional wall retreat rate of 5 to $10 \mathrm{~cm} / 100 \mathrm{ka}$, corresponding to an average rate of about $0.001 \mathrm{~mm} / \mathrm{a}$. At this rate it would take $20 \mathrm{ka}$ to form the scallop, which is a gross overestimate, as the corrosion was most likely discontinuous.

If Nonshauggrotta was widened from the proto-cave stage $(>1 \mathrm{~cm}$, Ford and Williams, 2007) to the present conduit size (mean width $=1.2 \mathrm{~m}$, max dissolved width $\approx$ $2.0 \mathrm{~m}$ ) during the last glaciation, this would have required a mean subglacial wall-retreat rate between 0.006 and $0.01 \mathrm{~mm} / \mathrm{a}$. This is about 10 times higher than the subglacial rate measured by direct radiometric dating. Based on this estimate, no unequivocal statement can be made on whether the cave evolved during the last or several of the latest glaciations. Evolution of the cave during the about $4 \mathrm{ka}$ of the last deglaciation, when large amounts of water were available, would have required a wall-retreat rate of about $0.2 \mathrm{~mm} / \mathrm{a}$. This rate is equal to the present wall retreat rate by an allogenic stream and 200 times higher than the subglacial rate of Lauritzen (1990). That would be an improbable dissolution rate for subglacial water, which is characterized by low aggressiveness (Tranter et al., 1993), in the moderate quantities permitted by the slow flow velocity observed. Accordingly, we may state that the cave is certainly older than the last deglaciation.

\section{Conclusions}

Nonshauggrotta is a network cave situated in a topographically and hydrologically hanging position. It was developed under artesian water flow towards the confining mica-schist cap rock. Its stratigraphic position just below the confining cap-rock was controlled by the contact, as there is no correlation between purity of the marble and the location of the passages.

Nonshauggrotta and Lønngangen are both developed along orthogonal fracture sets. We suggest that the different orientations of the guiding fractures in the two caves is a result of local structure; Nonshaugen is located in the hinge area and Lønngangen in the fold limb of the Sørfjorden antiform.

The network of Nonshaugen ridge had an effluent flow function, and we suggest that the network was fed from the south by a few feeder tubes. This is supported by the caves' architecture and the paleoflow pattern of Upper Nonshauggrotta. However, the consistent flow direction toward the northeast in Nonshauggrotta indicates an 
additional flow component along the cliff face. Accordingly, the network was probably fed from the southwestern or western side of the ridge as well.

Lønngangen is a short cave with an angular passage pattern and seems to have developed by phreatic water flow parallel to the cliff face. The cave does not display a proper maze pattern.

The flow functions of Upper Nonshauggrotta and Lønngangen may serve to demonstrate the two suggested recharge components of Nonshauggrotta separately. Upper Nonshauggrotta displays a single north-trending artesian feeder tube with a rudimentary labyrinth structure towards the cliff face that was developed in a confined setting. Lønngangen displays a rudimentary network developed along an escarpment with both recharge conduits and outflow conduits, but few closed loops. We may speculate that a combination of two flow components might have created the elaborate labyrinth of Nonshauggrotta.

All observations support the hypothesis that the maze caves were developed under subglacial conditions related to wet-based, topographically directed glacier flow. The consistently slow water flow in the Nonshaugen caves implied by scallop morphometry and sediment distribution makes us suggest that the ice-surface slope was very gentle, that the ice contact restricted outflow, or both.

\section{ACKNOWLEDGEMENTS}

The work of this paper was funded by the Research Council of Norway, grant No. 160232/V30 "Porosity development in marble stripe karst." David St. Pierre, Helge Skoglund, Terje Solbakk, and Arnfinn Jonsen are thanked for their assistance during cave surveys. Elsa Norum is thanked for her hospitality during field work. Walter Wheeler and Derek Ford are thanked for constructive comments that improved the manuscript. Statens Kartverk provided the aerial photos in Fig. 7 and 10.

\section{REFERENCES}

Bergh, S.G., Eig, K., Kløvjan, O.S., Henningsen, T., Olesen, O., and Hansen, J.-A., 2007, The Lofoten-Vesterålen continental margin: a multiphase Mesozoic-Palaeogene rifted shelf as shown by offshoreonshore brittle fault-fracture analysis: Norwegian Journal of Geology, v. 87 , p. $29-58$.

Corbel, J., 1957, Les karsts du nord-ouest de l'Europe et de quelques régions de comparaison: Institut des études rhodaniennes de l'Universite de Lyon, Mémoires et Documents 12, $541 \mathrm{p}$.

Curl, R.L., 1974, Deducing flow velocity in cave conduits from scallops: NSS Bulletin, v. 36, no. 2, p. 1-5.

Curl, R.L., 1986, Fractal dimensions and geometries of caves: Mathematical Geology, v. 18, p. 765-783.

Day, A., 2002, Cave Surveying: Buxton, British Cave Research Association, Cave Studies Series 11, 40 p.

Eikeland, R., 1986, Lønngangen: Norsk Grotteblad, v. 16, p. 25-26.

Feder, J., 1988, Fractals: New York, Plenum Press, Physics of Solids and Liquids series, $283 \mathrm{p}$.

Ford, D.C., 1977, Karst and glaciation in Canada, in Proceedings, $7^{\text {th }}$ International Speleological Congress: Sheffield, British Cave Research Association, p. 188-189.
Ford, D.C., and Williams, P., 2007, Karst hydrogeology and geomorphology, $2^{\text {nd }}$ edition: Chichester, John Wiley and Sons Ltd, $562 \mathrm{p}$.

Frumkin, A., and Fischhendler, I., 2005, Morphometry and distribution of isolated caves as a guide for phreatic and confined paleohydrological conditions: Geomorphology, v. 67, p. 457-471.

Gabrielsen, R.H., Braathen, A., Dehls, J., and Roberts, D., 2002, Tectonic lineaments of Norway: Norwegian Journal of Geology, v. 82, no. 3, p. $153-174$.

Gustavson, M., 1985, Glomfjord, foreløpig berggrunnsgeologisk kart: Norges Geologiske Undersøkelse, 1928 I, 1:50 000.

Gustavson, M., and Solli, A., 1989, Berggrunnskart Gildeskål: Norges Geologiske Undersøkelse, 1929 II, 1:50 000.

Horn, G., 1937, Über einige Karsthöhlen in Norwegen: Mitteilungen für Höhlen und Karstforschung, p. 1-15.

Klimchouk, A.B., 2003, Conceptualisation of speleogenesis in multi-storey artesian systems: a model of transverse speleogenesis: Speleogenesis and Evolution of Karst Aquifers, v. 1, no. 2, 18 p. [Available at http:// speleogenesis.info/pdf/SG2/SG2_artId24.pdf.]

Klimchouk, A.B., 2009, Principal features of hypogene speleogenesis, in Klimchouk, A.B., and Ford, D.C., eds., Hypogene Speleogenesis and Karst Hydrogeology of Artesian Basins: Simferopol, Ukrainian Institute of Speleology and Karstology Special Paper 1, p. 7-16.

Lauritzen, S.E., 1982, The paleocurrents and morphology of Pikhåggrottene, Svartisen, North Norway: Norsk Geografisk Tidsskrift, v. 36, p. $183-209$

Lauritzen, S.E., 1989, Scallop dominant discharge, in Proceedings, $10^{\text {th }}$ International Speleological Congress, v. 1: Budapest, Hungarian Speleological Society, p. 123-124.

Lauritzen, S.E., 1990, Tertiary caves in Norway: a matter of relief and size: Cave Science, v. 17, no. 1, p. 31-37.

Lauritzen, S.E., 2001, Marble stripe karst of the Scandinavian Caledonides: An end-member in the contact karst spectrum: Acta Carsologica, v. 30 , no. 2 , p. $47-79$.

Lauritzen, S.E., 2004, Grottolf Program for processing, plotting and analysis of cave survey data, University of Bergen.

Lauritzen, S.E., 2006, Caves and speleogenesis at Blomstrandsøya, Kongsfjord, W. Spitsbergen: International Journal of Speleology, v. 35 , no. 1 , p. $37-58$.

Lauritzen, S.E., and Lundberg, J., 2000, Solutional and erosional morphology of caves, in Klimchouk, A.B., Ford, D.C., Palmer, A.N., and Dreybrodt, W., eds., Speleogenesis: Evolution of Karst Aquifers: Huntsville, Alabama, National Speleological Society, p. $406-426$.

Linge, H., Olsen, L., Brook, E.J., Darter, J.R., Mickelson, D.M., Raisbeck, G.M., and Yiou, F., 2007, Cosmogenic nuclide surface exposure ages from Nordland, northern Norway: implications for deglaciation in a coast to inland transect: Norwegian Journal of Geology, v. 87, p. 269-280.

Loucks, R.G., 1999, Paleocave carbonate reservoirs: Origins, burial-depth modifications, spatial complexity, and reservoir implications: American Association of Petroleum Geologists Bulletin, v. 83, p. 17951834

Mangerud, J., 2004, Ice sheet limits on Norway and the Norwegian continental shelf, in Ehlers, J., and Gibbard, P., eds., Quaternary Glaciations - Extent and Chronology: Part 1 Europe: Amsterdam, Elsevier, Developments in Quaternary Science series 2, p. 271-294.

Nesje, A., and Sulebak, J.R., 1994, Quantification of late Cenozoic erosion and denudation in the Sognefjord drainage basin, western Norway: Norsk Geografisk Tidsskrift, v. 48, p. 85-92.

Olsen, L., 1997, Rapid shifts in glacial extension characterize a new conceptual model for glacial variations during the Mid and Late Weichelian in Norway: Norges Geologiske Undersøkelse Bulletin, no. 433 , p. $54-55$.

Palmer, A.N., 1975, The origin of maze caves: National Speleological Society Bulletin, v. 37 , no. 3, p. 56-76.

Palmer, A.N., 1991, Origin and morphology of limestone caves: Geological Society of American Bulletin, v. 103, p. 1-21.

Palmer, A.N., 2001, Dynamics of cave development by allogenic water: Acta Carsologica, v. 30, no. 2, p. 13-32.

Palmer, A.N., 2002, Speleogenesis in carbonate rocks, in Gabrovšek, F., ed., Evolution of Karst: From Prekarst to Cessation: Ljubljana, Inštitut za raziskovanje krasa, ZRC SAZU, p. 43-59. 
Rasmussen, A., 1981, The deglaciation of the coastal area NW of Svartisen, Northern Norway: Norges Geologiske Undersøkelse Bulletin, no. 369, p. 1-31.

Sejrup, H.P., Larsen, E., Landvik, J., King, E.L., Haflidason, H., and Nesje, A., 2000, Quaternary glaciations in southern Fennoscandia: evidence from southwestern Norway and the northern North Sea region: Quaternary Science Reviews, v. 19, p. 667-685.

Simanca, S.R., and Sutherland, S., 2002, Fractal Dimension, in Mathematical Problem Solving with Computers, coarse notes for MAT 331 at University of Stony Brook, http://www.math.sunysb.edu/ $\sim$ scott/Book331/Fractal_Dimension.html, [accessed July 5, 2009].

Skoglund, R.Ø., Lauritzen, S.E., and Gabrovšek, F., 2010, The impact of glacier ice-contact and subglacial hydrochemistry on evolution of maze caves: a modeling approach. Journal of Hydrology, (in press; posted online 2010)
Stephens, M.B., Gustavson, M., Ramberg, I.B., and Zachrisson, E., 1985, The Caledonides of central-north Scandinavia - a tectonostratigraphic overview, in Gee, D.G., and Sturt, B.A., eds., The Caledonide Orogen - Scandinavia and Related Areas, Part 1: Chichester, U.K., John Wiley and Sons Ltd., p. 135-162.

Sundborg, Å., 1956, The river Klarälven, a study of fluvial processes: Geografiska Annaler, v. 38, p. 125-237.

Tranter, M., Brown, G., Raiswell, R., Sharp, M., and Gurnell, A., 1993, A conceptual model of solute acquisition by Alpine glacial meltwaters: Journal of Glaciology, v. 39, p. 573-580.

Wells, M.K., and Bradshaw, R., 1970, Multiple folding in the Sørfinnset area of Northern Nordland: Norges Geologiske Undersøkelse Bulletin, no. 262, 89 p.

White, W.B., 1969, Conceptual models of carbonate aquifers: Groundwater, v. 7 , p. $15-21$. 